\title{
KATEKIS DAN RADIASI KOHESIF DI MEDAN POLITIK KERAGAMAN
}

\author{
Oleh: Anselmus D. Atasoge
}

\begin{abstract}
Abstrak:
Sejumlah masalah besar, seperti dampak negatif globalisasi dan teknologi, internasionalisasi kejahatan, konflik sipil dan terorisme serta masalah sehari-hari yang berkaitan dengan kejahatan lokal, perilaku anti-sosial, dan intoleransi rasial sedang menghinggapi dunia dewasa ini. Homogenitas identitas nasional yang menyumbang bagi kohesi sosial seakan diruntuhkan di era 'post-nasional' oleh proliferasi kelompok dan identitas daerah dari bawah dan oleh perkembangan organisasi politik supra-nasional dan masyarakat sipil trans-nasional dari atas. Politik identitas seakan menggerogoti bangunan bhineka tunggal ika. Tahun politik 2018/2019 menjadi medan empuk pemunculan wajah sosial-politik semacam ini. Di titik ini, para katekis yang adalah bagian penting dari agen-agen pastoral masa kini ditantang untuk menghadirkan diri sebagai pribadi dan kelompok kohesif. Diskursus ini mencoba meletakkan dasar bagi penghadiran-penghadiran semacam itu.
\end{abstract}

\section{Kata Kunci:}

Katekis, Kohesi Sosial, Modal Sosial, Politik Keragaman.

\section{Pengantar}

$\mathrm{B}$ isnis yang dimainkan 'saracen', komunitas tukang bikin berita dan informasi tipu-tipu itu memiliki 800.000 akun facebook yang telah diretasnya dan berada di bawah koordinasinya. Mereka berhasil mengolah informasi bohong menjadi pemberitaan yang dikutip media massa dan disebarluaskan melalui media sosial secara cepat hanya dalam hitungan menit. Kabar, berita, informasi yang disebar bernuansa memorak-porandak kohesi sosial-politik. Tujuan mereka adalah menyebar fitnah terhadap orang perorangan yang pada umumnya hendak berpartisipasi dalam konstelasi pilkada. Atau, nampak pula bahwa masing-masing kontestan pilkada saling serang, saling sebar fitnah. Untuk mengelola 'produk saling serang', saracen menjadi 'terminalnya'. Satu hal yang pasti adalah bahwa ada 'pihak-pihak' tertentu yang 'memesan kemasan bisnis hoaks' ini. Tinggal siap proposal dan disetujui durasi sebarannya serta sepakat biayanya, maka kabar, berita, informasi hoaks siap 'terbang' ke seantero jagad. ${ }^{1}$ Di tangan 'komunitas saracen', hoaks dimodifikasi jadi 'sarana pembunuh karakter' tokoh-tokoh lawan politik. Di tangan mereka pula kebohongan dimetamorfosiskan menjadi kebenaran. Di pikiran merekalah ilusi dipaksa jadi fakta dan kebenaran dipasung dalam jeruji besi yang amat kelam.

Hoaks dimodif secara sistematis sehingga tak gampang dibedakan: mana yang benar mana yang salah. Dan, akan menjadi sosial jika orang menaruh kepercayaan pada yang salah serentak menganggapnya benar dan memegangnya sebagai pedoman dalam membangun persepsi dan konsepsi sosial kemasyarakatan. Di titik ini, kohesi sosial kemasyarakatan jadi taruhannya. Masing-masing pihak bisa mengklaim diri

${ }^{1}$ Kompas, 25/8/2017 menyebutkan bahwa pada masa-masa penyelenggaraan pemilihan kepala daerah, misalnya, Saracen menawarkan tariff Rp. 60 juta hingga Rp. 70 juta. Biaya itu diperuntukkan bagi masa kerja satu bulan dalam memproduksi informasi hoaks yang menyudutkan lawan. Biasanya informasi itu akan menjadi viral di media-media sosial. 
sebagai yang paling benar, sebagai yang 'tersuci' di antara semua calon kepala daerah. Masyarakat atau kelompok sosial yang gampang termakan isu SARA akan lebih mudah terbangkitkan emosi sosialnya ketika 'kemasan saracen' menjadi konsumsi kelompoknya. Bukan tidak mungkin bila emosi sosial itu berubah menjadi 'amukan sosial' yang berwajah kekerasan yang berdampak negatif terhadap kohesi sosial keindonesiaan kita.

Produk-produk 'kemasan saracen' seakan lahir dalam wajah yang baru di tahun politik (2018-2019) ini melalui sajian-sajian politik di pelbagai media sosial. Sajiansajian itu tak jarang menampilkan celoteh-celoteh, sindiran-sindiran bahkan caci-maki yang bernuansa politis, menyerang tokoh tertentu, institusi tertentu termasuk simbolsimbol negara. Masyarakat berhadapan dengan 'sebuah dunia yang saling menelanjangi' yang kebenaran-kebenarannya masih harus diuji. Kasarnya, sajian yang belum tentu benar.

Ketika sajian-sajian itu diterima tanpa dikritisi, ketika itu pula tersebarlah ketidakbenaran-ketidakbenaran informasi ataupun pengetahuan-pengetahuan umum terutama yang terkait dan dikait-kaitkan dengan perpolitikan nasional dan lokal. Bukan tidak mungkin jika kondisi-kondisi ini membuat bangsa ini 'berjalan' dalam lembah kekelaman informasi dan pengetahuan.

Di satu sisi, ketika apa yang diwartakan itu diterima dan diteruskan secara luas tanpa terkendali ini maka di titik ini terjadilah pembalikan-pembalikan kebenaran secara tak berkesudahan. Pembalikan itu menyata dalam tendensi-tendesi saling menyalahkan, saling menggempur kelemahan individual, dan saling menyirami peradaban damai dengan api dengki dan amarah yang tak terkendali hingga tergerus dan melemahnya etika dan moral berpolitik. Apa yang diyakini sebagai kebaikankebaikan peradaban bangsa ini telah dibalik-balikan sesuai kehendak politik kelompok atau pribadi tertentu.

Pembalikan-pembalikan ini bukan tidak mungkin membuat masyarakat bangsa ini mengalami apa yang disebut Leon Festinger sebagai disonansi kognitif. ${ }^{2}$ Ketika orang berhadapan dengan pembalikan-pembalikan ini, ada kemungkinan bahwa orang akan merespon pembalikan itu dengan menghadirkan kecenderungan-kecenderungan negatif yang mengarah kepada perubahan perspektif dan tindakan praktis.

Di dunia politik, misalnya, kecenderungan itu bisa menyata dalam respon yang sepi terhadap para pemimpin politik yang arah dan sikap politiknya diwarnai dengan pembalikan-pembalikan itu. Politik yang diyakini sebagai 'sarana' untuk menghadirkan kebaikan bersama tak dihadirkan sebagaimana demikian. Hal itu terjadi karena politik yang sejatinya merupakan sebuah 'kesenian' untuk mengatur kemajemukan kepentingan demi kebaikan bersama telah dipandang sebagai 'seni mengejar kekuasaan' dengan pelbagai cara.

Diskursus ini bersentuhan dengan wacana sosiologis tentang kohesi sosial. Wacana ini telah menjadi diskusi panjang dalam kajian-kajian dan debat-debat sosiologis terutama ketika diskusi itu bersentuhan dengan gagasan besar tentang tatanan sosial. Tokoh-tokoh terkemuka dalam wacana ini di antaranya, Marx, Weber dan Durkheim. Marx dan Weber menghadirkan gagasan yang umumnya dikenal sebagai teori konflik. Keduanya memandang bahwa Durkheim pada posisi lain

\footnotetext{
${ }^{2}$ Peter L. Berger, The Many Altars of Modernity. Toward a Paradigm for Religion in a Pluralist Age (Walter de Gruyter: Germany, 2014), hal. 2.
} 
menghadirkan gagasan yang umumnya dikenal sebagai teori harmoni. Durkheim memandang bahwa hal yang paling utama dan menonjol dalam setiap masyarakat adalah peran para aktor sosial yang ada di dalam masyarakat skala kecil yang telah terintegrasi secara terpadu. Durkheim meletakkan kepercayaannya pada gagasan bahwa harmoni dan bukannya konfliklah yang mendefinisikan keberadaan dan keadaan masyarakat. Durkheim berangkat dari kajiannya tentang fenomena sosial yang berkaitan dengan peran dan fungsi setiap anggota masyarakat dalam membentuk dan menghasilkan apa yang disebut kohesi sosial.

Pertanyaan utama dalam diskursus ini adalah di manakah dan bagaimanakah para katekis katolik menghadirkan dirinya untuk mengikat-satukan individu-individu dalam satu institusi sosial yang memiliki tatanan sosial yang saling berinteraksi melalui proses-proses sosial. ${ }^{3}$ Lebih spesifik, jika tugas dan karya para katekis tak terelakkan dari fakta sosial politis yang melingkunginya, jalan-jalan manakah yang bisa dilaluinya untuk memaknai dunia politik saat ini? Aktivitas menghadirkan diri tersebut saya pandang sebagai peran radiasi seorang atau sekelompok katekis di medan politik.

\section{Kohesi Sosial: Harmoni, Identitas dan Kekhawatirannya}

Kohesi sosial menjadi sebuah konsep yang lahir dan terbentuk dengan sejarah yang panjang dan kompleks dalam ranah pemikiran sosial, politik dan ekonomi. Pada abad ke-19 misalnya, gagasan seputar tatanan sosial dan kohesi sosial bahkan menjadi tema-tema sentral dalam sosiologi seperti yang dikembangkan oleh Karl Marx dengan gagasan utamanya tentang pembagian kerja, Herbert Spencer dengan isu utamanya tentang evolusi sosial dan Emile Durkheim dengan teori khususnya tentang pembangunan sosial serta yang dikembangkan lebih lanjut oleh Talcott Parsons terkait bentuk dasar integrasi kemasyarakatan sebagai sistem norma, mengambil bentuk dalam budaya sipil dan politik dalam kerangka negara modern. ${ }^{4}$

Andy Green, John Preston dan Jan Germen Janmaat menyebutkan bahwa istilah itu merujuk pada kondisi kemasyarakatan yang relatif harmonis yang ditandai oleh rendahnya tingkat kejahatan dan tingginya tingkat kepercayaan antara individu dan masyarakat yang dibangun atas dasar kepercayaan. ${ }^{5}$ Jika diperluas, kondisi masyarakat yang relatif harmonis itu mencakup pula masyarakat dengan toleransi yang

${ }^{3}$ Gagasan tentang proses sosial dan interaksi sosial dalam tulisan ini merujuk pada John Lewis Gillin dan John Philip Gillin serta Kimball Young dan Mack W. Raymond. Lihat, Kimball Young dan Mack W. Raymond, Sociology and Social Life (New York: American Book Company, 1959), hal. 137. Menurut keduanya, tak akan ada kehidupan bersama tanpa interaksi sosial. Dengan kata lain, interaksi sosial menjadi kunci dari kehidupan sosial. Interaksi sosial menjadi dasar dari proses sosial yakni kesaling-pengaruhan antara satu individu dengan individu lain atau satu kelompok dengan kelompok yang lain, tidak sekedar secara badaniah belaka, melainkan dalam pelbagai segi kehidupan. Lihat pula John Lewis Gillin dan John Philip Gillin, Sociology, a revision of An Introduction to Sociology (New York: The Macmillan Company, 1954), hal. 489. Keduanya memandang interaksi sosial sebagai hubungan-hubungan sosial yang sifatnya dinamis antara orang perorang, antara kelompok-kelompok manusia dan antara orang perorang dengan kelompok manusia. Dalam konteks yang sederhana, hubungan itu menyata dalam bentuk-bentuk seperti saling bertegur-sapa, berjabat tangan, berbicaradialog-komunikasi ataupun dalam bentuk situasi luar biasa seperti perkelahian dan peperangan.

${ }^{4}$ Ian Gough dan Gunnar Olofsson, 'Introduction: New Thinking on Exclusion and Integration' dalam I. Gough and G. Olofsson, Capitalism and Social Cohesion: Essays on Exclusion and Integration (Basingstoke: Macmillan/Palgrave Macmillan, 1999), hal. 1-4.

${ }^{5}$ Andy Green, John Preston dan Jan Germen Janmaat, Education, Equality and Social Cohesion A Comparative Analysis (Palgrave Macmillan, Houndmills, Basingstoke, Hampshire RG21 6XS dan 175 Fifth Avenue, New York, 2006), hal. 4. 
tinggi antara individu yang satu terhadap individu lain, juga antara budaya yang satu terhadap budaya yang lain dan agama yang satu dengan agama yang lain. Kondisi ini dipandang sebagai prasyarat untuk menciptakan dan membangun kerjasama antarindividu dan individu dengan masyarakat.

Dalam konteks yang berbeda, bagi Andy Green, dkk, penggunaan istilah kohesi sosial hendak menekankan beberapa gagasan besar di antaranya norma dan nilai; perasaan identitas bersama atau kepemilikan umum masyarakat; kontinuitas dan stabilitas; masyarakat dengan institusi yang rela berbagi risiko dan memberikan kesejahteraan kolektif; keadilan distributif atas hak, peluang, kekayaan, dan penghasilan; dan masyarakat sipil yang kuat dan warga negara yang aktif.

Senada dengan gagasan itu, menurut Jane Jensen, istilah kohesi sosial digunakan untuk menggambarkan sebuah proses yakni pelibatan komitmen dan keinginan atau kapasitas untuk hidup bersama dalam keharmonisan. Bagi Jensen, untuk mencapai hal ini tidak perlu melibatkan banyak orang dan nilai-nilai, karena terlalu banyak 'ikatan' dan kesesuaian nilai dapat menyebabkan stagnasi dan menciptakan komunitas yang bersifat tertutup. ${ }^{6}$

Menurut Judith Maxwell, seperti yang dikutip Andy Green, John Preston dan Jan Germen Janmaat, di sisi lain, kohesi sosial melibatkan pembangunan berbagi nilai dan komunitas penafsiran, mengurangi kesenjangan kekayaan dan pendapatan, dan umumnya memungkinkan orang untuk memiliki rasa bahwa mereka terlibat dalam usaha bersama, menghadapi tantangan bersama, dan bahwa mereka adalah anggota dari komunitas yang sama. ${ }^{7}$

Dalam konteks seperti ini, Michalski, Miller dan Stevens membuat sketsa dua skenario alternatif untuk pengembangan dan peningkatan kohesi sosial di masa depan. Pertama, skenario individualistik memperkirakan peningkatan fleksibilitas sosial melalui pengurangan pemerintah dan regulasi dan sebuah perpanjangan hak dan pilihan individu melalui pasar. Kohesi di sini sebagian besar bergantung pada aspirasi bersama yang ditopang oleh pertumbuhan ekonomi dan peningkatan peluang pribadi. Kedua, skenario solidaristik yang membayangkan nilai-nilai bersama secara luas berdasarkan institusi kolektif dan publik yang kuat. ${ }^{8}$

Karena itu, fokus utama kohesi sosial berusaha untuk memerangi segala bentuk pengecualian dan memastikan bahwa kelompok yang paling rentan dan terpinggirkan termasuk dalam masyarakat sipil. Dengan demikian, kohesi sosial juga merupakan konsep yang mencakup nilai-nilai dan prinsip-prinsip yang bertujuan untuk memastikan bahwa semua warga negara, tanpa diskriminasi dan dengan pijakan yang sama, memiliki akses kepada hak sosial dan ekonomi. Konsep ini menghadirkan ingatan akan kebutuhan kolektif untuk memperhatikan dan menyadari segala jenis diskriminasi, ketidaksetaraan, dan marginalitas. Untuk mencapai idealisme itu, diperlukan kesadaran dan tindakan pengakuan atas perbedaan berdasarkan budaya, ras,

${ }^{6}$ Jane Jensen, Mapping Social Cohesion: The State of Canadian Research (Ottawa: Canadian Policy Research Networks Inc., 1998), hal. 1.

${ }^{7}$ Andy Green, John Preston dan Jan Germen Janmaat, Op.Cit., hal. 4.

${ }^{8}$ W.Michalski, R. Miller, dan B. Stevens, 'Economic Flexibility and Societal Cohesion in the Twenty-First Century: An Overview of Issues and Key Points of Discussion,' dalam OECD, Societal Cohesion and the Globalizing Economy: What Does the Future Hold? (Paris: OECD, 1997). 
jenis kelamin, bahasa ibu, agama, usia dan banyak atribut manusia lainnya dan kebutuhan untuk mengakomodasi perbedaan-perbedaan ini. ${ }^{9}$

Situasi kebalikannya seperti ketidaksetaraan dalam pemenuhan hak sosial dan ekonomi dipandang Wacquant sebagai tantangan-tantangan yang berdampak pada merusaknya kohesi sosial. ${ }^{10}$ Selain itu, kohesi sosial juga dirusak oleh kekerasankekerasan di dalam dan antar komunitas yang dimanifestasikan dalam kerusuhan etnis dan ras termasuk juga yang berlabelkan agama. Wacquant mencatat bahwa selama dua dekade terakhir, negara-negara di dunia telah diganggu oleh ledakan keresahan publik dan meningkatnya ketegangan etnis dan rasial. ${ }^{11}$

\section{Jaringan Sosial, Modal Sosial dan Kohesi Sosial}

Buku "What Hold Us Together" yang diedit oleh David Chidester, Phillip Dexter dan Wilmot James memberi perspektif spesifik tentang jaringan-jaringan sosial sebagai modal sosial bagi kohesi sosial. Mereka memandang komunitas keluarga inti dengan kemesraan yang tercipta di dalamnya; budaya jalanan di perkotaan yang diperankan oleh para pemuda kota yang hadir dengan gaya musik, puisi dan seni visual termasuk juga para tunawisma di perkotaan dan gerakan sosial baru di Afrika Selatan yang lahir sebagai dampak dari relasi-relasi dengan masyarakat di luar Afrika Selatan sebagai bentuk-bentuk kohesi sosial. ${ }^{12}$ Relasi-relasi lokal dan global ini dipersatukan dan diikat-eratkan oleh imajinasi, kreativitas dan identitas sebagai sumber daya manusia yang kemudian membentuk budaya dan realitas sosial Afrika Selatan. Budaya dan kenyataan sosial ini dipandang sebagai sumber daya simbolis dan menempatkannya sebagai unsur pembangun negosiasi identitas manusia, secara individu dan kolektif, dalam dan demi suatu perubahan Afrika Selatan dalam konteks globalisasi.

Jaringan-jaringan sosial ini menjadi modal sosial dalam membentuk kohesi sosial serentak menjadi indikator dari kohesi sosial. David Chidester, Phillip Dexter dan Wilmot James memandang modal sosial sebagai jaringan sosial yang terbangun di atas dasar kesaling-percayaan satu sama lain. Jaringan ini memungkinkan setiap individu dan kelompok berpartisipasi dan saling mendukung dalam melakukan aksi kolektif untuk mencapai tujuan bersama. ${ }^{13}$ Jika demikian, maka dalam konteks

${ }^{9}$ Andrew Markus and Liudmila Kirpitchenko, "Conceptualising Social Cohesion” dalam James Jupp dan John Nieuwenhuysen, Social Cohesion in Australia (Cambridge University Press: New York, 2007), hal. 29.

${ }^{10}$ L.J.D. Wacquant, "Thereturnof therepressed: urbanviolence, "race", anddualization in three advanced societies'. Plenary address presented at the XVII Encontro Anual da ANPOCS, October 1993, at Caxambu, Brazil, 1993, hal. 6.

${ }^{11}$ Ibid., hal. 3. Bdk. Chaiwat Satha-Anand, “Barangsiapa Memelihara Kehidupan...”'Esai-esai tentang Nirkekerasan dan Kewajiban Islam, disunting oleh Ihsan Ali-Fauzi, Rizal Panggabean dan Irsyad Rafsadi (PUSAD: Jakarta, 2015), hal. 29-59. Sejarah internasional menyuguhkan banyak bukti tentang perang antar-bangsa yang berbeda agama maupun perang antar-bangsa yang memeluk agama yang sama. Dengan memperhatikan fenomena peperangan di abad ke-20, ada sementara orang menamakan abad ini dengan sebutan "abad perang total": Korban perang pesat jumlahnya; penggunaan teknologi (pembasmi kehidupan, bukan saja sasaran perang melainkan juga 'jiwa manusia lain_sipil dan juga tumbuhan, hewan, lingkungan'); dan terorisme.

12 David Chidester, Phillip Dexter dan Wilmot James, "Introduction" dalam Phillip Dexter dan Wilmot James, What Hold Us Together (HSRC Press, Cape Town: South Africa, 2003), hal. 1-2.

${ }^{13}$ Ibid., hal. 323. 
kehidupan yang lebih luas, modal sosial juga dipandang sebagai kunci pembangunan demokrasi dan bidang-bidang kehidupan lainnya.

Perlu ditekankan kembali bahwa sikap saling percaya tampil sebagai prasyarat bagi modal sosial. Prasyarat lain yang mengikuti sikap ini adalah kesaling-simpatian antara individu-individu atau komunitas-komunitas. Di balik kedua prasyarat ini timbul pula semacam kewajiban-kewajiban sosial di antara individu dan komunitaskomunitas. Kewajiban sosial mendorong individu dan komunitas kepada kebaikan bersama karena di dalamnya 'aku' dan 'engkau' tidak tampil lagi sebagai dua entitas yang berbeda melainkan telah melebur menjadi 'kita'. Kepercayaan, simpati dan kewajiban sosial pada gilirannya menghasilkan keuntungan-keuntungan potensial bagi kohesi sosial antar individu dan komunitas-komunitas masyarakat.

David Chidester, dkk menyebutkan bahwa bagi komunitas lokal, modal sosial bagaikan 'kekerabatan fiktif'. Istilah ini digunakan untuk jenis relasi dan hubungan di luar keluarga inti. Kekerabatan fiktif terakumulasi dalam dan melalui jejaring sosial, dibangun di atas dasar kepercayaan antara satu dengan yang lain, kesadaran simpatetik dan kewajiban bersama. Kekerabatan jenis ini memungkinkan setiap individu dan komunitas untuk menciptakan tindakan bersama berbasis masyarakat untuk memajukan kepentingan bersama. ${ }^{14}$

Andy Green, John Preston dan Jan Germen Janmaat menyebutkan bahwa dunia kini sedang diperhadapkan dengan sejumlah masalah besar, di antaranya dampak negatif globalisasi dan teknologi, internasionalisasi kejahatan, konflik sipil dan terorisme serta masalah sehari-hari yang berkaitan dengan kejahatan lokal, perilaku anti-sosial, dan intoleransi rasial. Homogenitas identitas nasional, yang dulu dianggap sangat penting bagi kohesi sosial seakan diruntuhkan di era 'post-nasional' oleh proliferasi kelompok dan identitas daerah dari bawah dan oleh perkembangan organisasi politik supra-nasional dan masyarakat sipil trans-nasional dari atas. ${ }^{15}$

Masalah-masalah ini menimbulkan kekhawatiran besar karena dipandang menjadi ancaman terhadap kohesi sosial. Mungkin prediksi Huntington (1996) tentang 'peradaban konflik', atau pesimistis Horsman dan Marshall (1994) tentang munculnya 'tribalisme baru' atau pertanyaan optimistis Touraine (2000) bertajuk 'Bisakah Kita Hidup Bersama?' menemui relevansinya dalam situasi dunia sekarang ini. Bukan tidak mungkin jika trend-trend sosial-politik ini menjadi tantangan bagi integritas kehidupan institusional dan sosial serta keberlanjutan pertumbuhan ekonomi bangsa-bangsa. ${ }^{16}$

\section{Katekis dan Radiasi Kohesif di Medan Politik Keragaman}

Kesadaran para katekis dan agen-agen pastoral pada umumnya akan jaringanjaringan dan modal-modal sosial yang telah hidup dalam masyarakat merupakan sebuah jalan kecil untuk memantapkan peran dan fungsinya sebagai agen-agen kohesif di tata dunia. Kesadaran ini pada gilirannya menguatkan pemahaman dasarnya akan eksistensinya di tengah tata dunia yang ditandai dengan kenyataan pluralistik.

\footnotetext{
${ }^{14}$ Ibid., hal. 330.

${ }^{15}$ Andy Green, John Preston dan Jan Germen Janmaat, Education, Equality and Social Cohesion A Comparative Analysis (Palgrave Macmillan: New York, 2006), hal. 1-2.

${ }^{16}$ Ibid.
} 
Sepanjang sejarah Indonesia bahkan sebelum masa kemerdekaannya, Indonesia yang bercorak multi-agama, multi-etnis-budaya tak sepenuhnya menikmati corak pluralisnya itu. ${ }^{17}$ Corak ke-Indonesia-an ini di satu sisi menjadi kekayaan bangsa namun di sisi lain mengandung pula tantangan. Ketika agama, kepercayaan atau model-model spiritualitas lokal lainnya (sebagai unsur-unsur dari kepluralitasan tersebut) telah masuk dan menjadi bagian dalam dan dari ruang publik, pluralitas menampilkan dua konsekuensi yang berbeda. Di satu pihak menjadi kekayaan ketika dia mengungkapkan berbagai kemungkinan jalan untuk mendekati Allah dan jalan untuk mewujudkan apa yang dipandang sesuai dengan maksud Allah untuk kebaikan manusia. ${ }^{18}$ Pada pihak lain, pluralitas merupakan sebuah tantangan yang jika tidak dikelola dengan baik dapat menjerumuskan negara-bangsa dalam pola pikir dan aksiaksi diskriminatif. ${ }^{19}$ Dalam sejarah Indonesia, jawaban terhadap tantangan ini tidak hanya diberikan dalam bentuk kehendak baik untuk menciptakan peacebuilding melainkan juga dalam bentuk ketegangan malahan bentrokan berdarah. ${ }^{20}$

Terkait hal ini, dalam laporan penelitiannya yang dirilis tahun 2015, CRCS memaparkan bahwa di Indonesia dalam 15 tahun terakhir ini, ada sejumlah jenis isu

${ }^{17}$ Syamsul Maarif, Pasang Surut Rekognisi Agama Leluhur dalam Politik Agama di Indonesia (CRCS: Yogyakarta, 2018), hal. 1. Lihat pula Jae Bong Park, Managing Socio-Economic Crisis in Indonesia (The Role of Interfaith Civic Organisations in Yogyakarta during the 1998 Economic Crisis (Indonesia and the Malay World Vol. 40, No. 116 March 2012), hal. 42.

${ }^{18}$ Bdk. Arya Gaduh, Uniter or Divider? Religion and Social Cooperation: Evidence from Indonesia, University of Southern California, October 2012, hal. 3. Bagi orang beriman, agama merupakan sumber nilai individu dan identitas sosial. Keyakinan agama menentukan perilaku individu yang pada akhirnya mempengaruhi hasil kesejahteraan dan ekonomi. Kecenderungan untuk kerja sama sosial adalah contoh perilaku yang sangat terkait dengan tradisi yang dibentuk oleh keyakinan agama.

19 Bdk. Chaiwat Satha-Anand, "Bulan Sabit Nirkekerasan: Delapan Tesis tentang Aksi Nirkekerasan Muslim" dalam Chaiwat Satha-Anand, "Barangsiapa Memelihara Kehidupan... "Esai-esai tentang Nirkekerasan dan Kewajiban Islam, disunting oleh Ihsan Ali-Fauzi, Rizal Panggabean dan Irsyad Rafsadi (PUSAD: Jakarta, 2015), hal. 29-59. Dalam bidang studi perang internasional, sejarah menyuguhkan banyak bukti tentang perang antar-bangsa yang berbeda agama maupun perang antarbangsa yang memeluk agama yang sama. Ada yang menamakan abad ke-20 sebagai "abad perang total". Korban perang naik pesat jumlahnya. Sepanjang sejarah modern, terutama sejak revolusi industri, teknologi banyak sekali pengaruhnya pada kemampuan melancarkan perang. Masalahnya menjadi semakin rumit dengan bertambah banyaknya terorisme. Alat perang teknologi modern: pembasmi kehidupan, bukan saja sasaran perang melainkan juga 'jiwa manusia lain_sipil dan juga tumbuhan, hewan, lingkungan'. Sejumlah persoalan internasional yang dilansir sebagai bagian dari konflik keagamaan dalam skala yang besar bisa disebutkan antara lain konflik Israel-Palestina, Sengketa Kashmir, Perang Salib, Perang Bosnia, dan Holocaust. Dan, sejumlah persoalan keagamaan lainnya yang dipandang sebagai sumber konflik antaragama yang akhir-akhir ini marak diperbincangkan di antaranya blasphemy (Lihat Allison Dimase, Replace Blasphemy With Incitement. How Indonesia should Promote Religious Harmony while Upholding Human Rights (Pustaka Masyarakat Setara: Jakarta, 2016); hate spin (Lihat Cherian George, Pelintiran Kebencian Rekayasa Ketersinggungan Agama dan Ancamannya bagi Demokrasi (PUSAD: Jakarta, 2017).

${ }^{20}$ Bdk. Zainal Abidin Bagir, "Pluralisme Kewargaan: Dari Teologi ke Politik" dalam Zainal Abidin Bagir, dkk, Pluralisme Kewargaan: Arah Baru Politik Keragaman di Indonesia (CRCS: UGM Yogyakarta, 2011), hal. 12. Pada umumnya, hubungan antaragama di Indonesia berjalan baik di hampir seluruh wilayah Indonesia. Namun, tak dapat dipungkiri bahwa relasi-relasi itu tak meninggalkan beberapa masalah. Bagir menulis bahwa dalam beberapa tahun terakhir, terkhusus pasca Reformasi 1998, ada sejumlah sumber ketegangan dalam hubungan antarkomunitas agama. Tak jarang ditemui bahwa ketegangan itu berubah menjadi kekerasan. Adapun kekerasan komunal ini melibatkan komunitas-komunitas beda agama dalam skala besar, seperti beberapa kasus yang terjadi di sekitar 1998. Lihat pula P. Tule, Allah Akbar, Allah Akrab (Ledalero: Maumere, 2003), hal. 7. Dalam keadaan seperti itu, suku, agama dan perasaan fanatisme nasional ataupun kedaerahan menjadi sasaran-sasaran yang dieksploitasi (menjadi alat politik) untuk mencapai tujuan-tujuan politis. 
utama yang muncul secara konsisten. Dikatakan, kekerasan komunal berskala besar cenderung menurun secara tajam, namun kekerasan-kekerasan sporadis yang terkait dengan "penodaan agama" atau isu pembangunan rumah ibadah tampak makin intens. Isu lain yang kerap muncul sebagai akibat demokratisasi adalah menguatnya wacana pro-kontra terkait pembuatan kebijakan-kebijakan publik, baik pada tingkat nasional maupun lokal. Ada tiga titik simpul dari penelitian ini, yakni pertama sebagai negara demokrasi dengan mayoritas penduduk memegang teguh identitas keagamaan, kontestasi untuk mendorong peran agama di ruang publik tidak terhindarkan. Kedua, terdapat beragam tingkat kemampuan masyarakat dan negara dalam mengelola keragaman di satu tempat dan tempat lain. Ada yang mengelolanya secara baik hingga terciptanya peacebuilding berdasarkan kearifan-kearifan lokal namun tak sedikit pula yang upaya pengelolaannya tidak menemukan hasil yang memuaskan. Ketiga, kapasitas masyarakat dan negara dalam mengelola keragaman sering menemui jalan terjal ketika tidak ditemuinya sinergisitas antar-elemen. Di sana-sini masih ditemui perbedaan perspektif, pendekatan, dan kesalahpahaman sehingga cita-cita akan kerukunan masih sulit dijangkau. ${ }^{21}$

Sejarah panjang bangsa Indonesia sejak keberadaannya tak terbebaskan dari situasi semacam ini. Diskursif ini tidak sampai pada titian yang mengkaji 'kisah' itu secara detail. Namun, sekedar gambaran dapatlah disebutkan rangkuman singkat 'kisah-kisah' itu pada sebuah masa tertentu saja. Misalnya, sepanjang tahun 2017 Setara Institute mencatat 155 peristiwa pelanggaran kebebasan beragama/berkeyakinan (gangguan terhadap rumah ibadat dan pelanggaran terhadap minoritas keagamaan) dengan 201 bentuk tindakan yang tersebar di seluruh Indonesia. Dibandingkan dengan tahun 2016, angka ini menunjukkan penurunan signifikan, yaitu 53 peristiwa dan 69 tindakan. $^{22}$ Keragaman Indonesia terutama yang bersinggungan dengan etnis, agama dan budaya menjadi tema 'pembelajaran' yang tak berkesudahan bagi bangsa Indonesia. Kesadaran akan keragaman yang tak akan pernah 'diseragamkan' mesti harus tetap dijaga.

Ikhtiar untuk menciptakan dan merawat perdamaian adalah jalan-jalan kecil untuk sampai pada cita-cita besar untuk mengeratkan kohesi sosial. Untuk konteks Gereja, ikhtiar itu diciptakan juga untuk menghidupi sukacita Injil di tengah keanekaragaman. Sejatinya, ikhtiar itu mesti berangkat dari 'dalam', dari niat yang tulus dan baik. Dan, keberangkatan yang sejati lahir dari pengetahuan dan kesadaran historis yang benar tentang kesamaan asal yang kemudian mewujud dalam jalan yang beranekaragam.

${ }^{21}$ Mohammad Iqbal Ahnaf (Penyunt.), Praktik Pengelolaan Keragaman di Indonesia. Kontestasi dan Koeksistensi (Center for Religious and Cross-cultural Studies/CRCS: Jogyakarta, 2015), hal. iii-v.

22 Lihat Presentasi Laporan Kondisi Kebebasan Beragama/Berkeyakinan dan Minoritas Keagamaan di Indonesia Tahun 2017 oleh Setara Institute, 15 Januari 2018. Sebagai perbandingan lihat pula Ashutosh Varshney, Rizal Panggabean dan Mohammad Zulfan, Patterns of Collective Violence in Indonesia (1990-2003), Jakarta, UNSFIR, 2004, hal. 1-37. Ada banyak bentrokan Muslim-Kristen sebelum tahun 1998 terutama pada tahun 1996-1997 seperti yang terjadi di Tasikmalaya (Jawa Barat), Banjarmasin (Kalimantan Selatan), Situbondo (Jawa Timur), dan Ujung Pandang (Sulawesi Selatan). Di tahun 1992-1997 kekerasan antar dua kelompok ini lebih banyak menyebabkan kerugian harta benda. Sementara, setelah tahun 1998 selain harta benda, nyawa juga ikut jadi korban secara signifikan. Kekerasan Muslim-Kristen di tahun 1970-an dan 1980-an tidak terlalu nampak. Kekerasan MuslimKristen, dengan demikian, bukanlah fenomena pasca-1998, melainkan telah dimulai jauh sebelum akhir Orde Baru. Bentuknya menjadi lebih fatal setelah tahun 1998. Lihat pula Suhadi, Protecting the Sacred: An Analysis of Local Perspectives on Holy Site Protection in Four Areas in Indonesia (CRCS: Yogyakarta, 2016), hal. 35-37. 
Tradisi agama-agama Abraham (Yahudi, Kristen, Islam), misalnya, memiliki beberapa kepercayaan fundamental yang sama yang menjadi landasan bagi setiap sikap toleran dan hormat terhadap keyakinan lain dan orang lain yang berbeda. Keyakinan yang sama tersebut mendorong munculnya sikap toleran dan sikap hormat tersebut. Pertama, merujuk pada iman Abraham. Iman Abraham adalah iman bahwa Allah yang berbelas kasih itu menguasai segala sesuatu dan bahwa penyerahan diri kepada kehendak penyelenggaraan Tuhan adalah jalan kebenaran bagi semua. Kedua, semua manusia adalah citra Allah. Pemahaman tentang manusia ini mendukung kepekaan yang sehat untuk hormat kepada pribadi lain. Nilai keilahian sebagai kecitraan Allah ini mendasari rasa hormat bagi setiap orang dan dibutuhkan bagi munculnya toleransi. Ketiga, pengakuan akan keterbatasan pribadi manusia. Bahwa manusia itu merupakan makluk yang terbatas, lemah dan dapat berbuat salah. Dengan adanya pengakuan seperti ini, kita dapat memperkirakan bahwa semua manusia termasuk diri kita dapat saja melakukan kesalahan dalam hal keyakinan maupun dalam praktek. Karenanya, menurut Kelly James Clark, umat beragama menyikapi keyakinannya sendiri dan keyakinan orang lain dengan dosis yang sehat yaitu dengan kerendahan hati sebagai sesama ciptaan. Pengakuan terhadap 'bisa salah' (kesalahan yang tak terelakkan) ini memberikan dorongan bagi rasa hormat yang nyata dan substantif terhadap siapa pun yang tidak bersepakat dengan kita. ${ }^{23}$ Di titik ini, menjadi relevan sebuah rangkuman yang ditulis oleh Miroslav Volf ${ }^{24}$ dengan bertitik tolak dari Surat 1 Petrus: "Jangkauan kasih Tuhan menjadi jangkauan dari sikap hormat kita. Karena yang pertama bersifat universal maka yang kedua juga demikian. Sebagaimana kasih Tuhan sungguhsungguh tanpa pandang bulu, merangkul manusia dari berbagai warna, keyakinan dan identitas entah mereka adalah orang suci yang paling terpuji atau pendosa yang paling tercela, maka sikap hormat kita juga harus tanpa pandang bulu."

Salah satu pernyataan penting dari Hedieh Mirandi adalah bahwa Tuhan dalam kearifanNya telah menciptakan semua jenis manusia. ${ }^{25}$ Dari keseluruhan ciptaanNya itu ada sebagian manusia yang menyembahNya, sebagian lainnya menyembah yang lain dan sebagiannya lagi tidak menyembah apapun. Meski demikian, tegas Mirandi, Tuhan tidak pernah menahan karunia ilahiah dan rahmatNya kepada siapapun di antara semua mereka. Tambahan pula, Tuhan tidak mengharuskan semua ciptaanNya hanya menerima satu agama saja.

Sebagai agen-agen kohesif di tengah keragaman, para katekis sejatinya adalah pribadi-pribadi yang seluruh jiwa raganya diabdikan pada penciptaan kohesi sosial, entah di dalam komunitasnya, Gerejanya maupun di tengah masyarakat yang plural. Hemat saya, sebagai bekal dalam tugas dan karyanya ini, beberapa prinsip di bawah ini boleh menjadi pegangannya. ${ }^{26}$ Pertama, siapapun di luar komunitas kita akan selalu bisa mengajarkan sesuatu yang berharga termasuk bagi tradisi-tradisi kita sendiri. Sikap yang dibutuhkan untuk memperoleh pengajaran ini adalah menyambut setiap

${ }^{23}$ Kelly James Clark, "Panggilan Anak-Anak Abraham" dalam Kelly James Clark (ed.), AnakAnak Abraham. Kebebasan dan Toleransi di Abad Konflik Agama (Yogyakarta: Kanisius, 2016), hal. 14-24.

${ }^{24}$ Miroslav Volf, "Hormatilah Setiap Orang! Iman Kristen dan Budaya Sikap Hormat Universal" dalam Kelly James Clark (ed.), Anak-Anak Abraham .... hal. 248-251.

${ }^{25}$ Hedieh Mirandi, "Jalan Tengah" dalam Kelly James Clark (ed.), Anak-Anak Abraham.... hal. 283-284.

26 Philip Huggins, Communication Making Peace Together, Faith and Reconciliation: Reflections of an Interfaith Dialogue Practitioner (Global Change, Peace \& Security, 2013), Vol. 25, No. 3, hal. 313. 
kesempatan untuk mendengarkan dan berbicara dengan orang lain tentang perjuangan mereka untuk berusaha hidup dengan kebenaran tertinggi yang mereka ketahui. Pertemuan-pertemuan dan kesempatan informal lainnya memungkinkan untuk menumbuhkan dan menikmati persahabatan dengan orang-orang dari tradisi dan budaya keagamaan lainnya.

Kedua, kesempatan untuk mendapatkan perspektif lain tersebut dicapai melalui persahabatan sejati. Persahabatan sejati dibangun di atas dasar kesaling-akraban menuju Allah yang akbar meski melalui jalan yang berbeda-beda. Persahabatan sejati mengarahkan setiap sahabat ke tujuan yang sama meski dengan cara yang khas dan unik menurut masing-masing agama.

Ketiga, setiap sahabat sejati adalah hadiah. Sama seperti saat kita menerima hadiah dari seseorang dengan ekspresi yang menggembirakan, demikian pula kita menyambut para sahabat dari pelbagai latar belakang dengan kehangatan yang memukau. Penyambutan sesama yang lain sebagai sebuah hadiah menyingkirkan pelbagai prasangka negatif tentang orang yang disambut sekaligus memaklumkan kepada dirinya bahwa dirinya adalah hadiah terindah bagi diri kita. Keempat, kemanusiaan universal, kehendak baik dan kepentingan bersama dapat membangun pemahaman dan kohesi sosial yang sejati pada saat pertemanan dimulai dan berkelanjutan. Kebersamaan dalam kesepahaman ini bisa menepis prasangkaprasangka buruk satu terhadap yang lain, baik pribadi orang perorangan dan hubungan satu dengan yang lain maupun struktur-struktur sosial kemasyarakatan sekaligus memupuskan harapan berkembangnya stereotip dari masing-masing unsur itu yang bisa menghanguskan kemanusiaan universal. ${ }^{27}$

Kelima, berbagai prinsip untuk membantu hubungan manusia yang lebih baik memiliki aplikasinya dalam satu ikhtiar untuk mendengarkan dengan saksama satu sama lain, tanpa mengganggu satu dengan yang lain. Banyak konflik memiliki dasarnya dalam ketiadaan sikap untuk mendengarkan satu sama lain. Selalu ada kemungkinan bahwa konflik antara satu dengan yang lain menjadi semakin meningkat ketika sebuah gangguan diikuti dengan gangguan-gangguan yang lain.

\section{Penutup}

Di tengah politik keragaman yang nampak kuat di Indonesia, kohesi sosial menjumpai tantangan yang kompleks. Pada situasi ini, para katekis dipanggil untuk menciptakan peradaban harmonis sebagai bagian dari cita-cita membangun kohesi sosial. Karena itu, kehadirannya di tengah masyarakat dan lingkungan sosialnya merupakan kehadiran yang menggelorakan kasih dan perdamaian, bukannya mempecundangi yang plural dengan pelbagai 'rekayasa saracen' dan atau menghadirkan dirinya sebagai 'saracenian'.

${ }^{27}$ Bdk. Reina C. Neufeldt, Interfaith Dialogue: Assessing Theories of Change (Peace \& Change, Vol. 36, No. 3, July 2011), hal. 344. 


\section{Daftar Kepustakaan}

Ahnaf, Mohammad Iqbal (Penyunt.). 2015. Praktik Pengelolaan Keragaman di Indonesia. Kontestasi dan Koeksistensi. Yogyakarta: Center for Religious and Cross-cultural Studies/CRCS.

Bagir, Zainal Abidin. Dkk. 2011. Pluralisme Kewargaan: Arah Baru Politik Keragaman di Indonesia. Yogyakarta: CRCS UGM.

Berger, Peter L. 2014. The Many Altars of Modernity. Toward a Paradigm for Religion in a Pluralist Age. Germany: Walter de Gruyter.

Dexter, Phillip dan Wilmot James. 2003. "Introduction" dalam Phillip Dexter dan Wilmot James, What Hold Us Together. South Africa: HSRC Press, Cape Town.

Dimase, Allison. 2016. Replace Blasphemy With Incitement. How Indonesia should Promote Religious Harmony while Upholding Human Rights. Jakarta: Pustaka Masyarakat Setara.

Gaduh, Arya. 2012. Uniter or Divider? Religion and Social Cooperation: Evidence from Indonesia. University of Southern California, October.

George, Cherian. 2017. Pelintiran Kebencian Rekayasa Ketersinggungan Agama dan Ancamannya bagi Demokrasi. Jakarta: PUSAD.

Gillin, John Lewis dan John Philip Gillin. 1954. Sociology, a revision of An Introduction to Sociology. New York: The Macmillan Company.

Gough, I. and G. Olofsson. 1999. Capitalism and Social Cohesion: Essays on Exclusion and Integration. Basingstoke: Macmillan/Palgrave Macmillan.

Green, Andy, John Preston dan Jan Germen Janmaat. 2006. Education, Equality and Social Cohesion A Comparative Analysis. New York: Palgrave Macmillan.

Huggins, Philip. Communication Making Peace Together, Faith and Reconciliation: Reflections of an Interfaith Dialogue Practitioner (Global Change, Peace \& Security, 2013), Vol. 25, No. 3.

Jensen, Jane. 1998. Mapping Social Cohesion: The State of Canadian Research. Ottawa: Canadian Policy Research Networks Inc.

James, Kelly Clark (ed.). 2016. Anak-Anak Abraham. Kebebasan dan Toleransi di Abad Konflik Agama. Yogyakarta: Kanisius.

Jupp, James dan John Nieuwenhuysen. 2007. Social Cohesion in Australia. New York, Cambridge University Press.

Laporan Kondisi Kebebasan Beragama/Berkeyakinan dan Minoritas Keagamaan di Indonesia Tahun 2017 oleh Setara Institute, 15 Januari 2018.

Maarif, Syamsul. 2018. Pasang Surut Rekognisi Agama Leluhur dalam Politik Agama $d i$ Indonesia. Yogyakarta: CRCS.

Neufeldt, Reina C. Interfaith Dialogue: Assessing Theories of Change (Peace \& Change, Vol. 36, No. 3, July 2011). 
Park, Jae Bong. Managing Socio-Economic Crisis in Indonesia (The Role of Interfaith Civic Organisations in Yogyakarta during the 1998 Economic Crisis (Indonesia and the Malay World Vol. 40, No. 116 March 2012).

OECD. 1997. Societal Cohesion and the Globalizing Economy: What Does the Future Hold? Paris: OECD.

Satha-Anand, Chaiwat. 2015. “Barangsiapa Memelihara Kehidupan...”Esai-esai tentang Nirkekerasan dan Kewajiban Islam, disunting oleh Ihsan Ali-Fauzi, Rizal Panggabean dan Irsyad Rafsadi. Jakarta: PUSAD.

Suhadi. 2016. Protecting the Sacred: An Analysis of Local Perspectives on Holy Site Protection in Four Areas in Indonesia. Yogyakarta: CRCS.

Tule, Philipus. 2003. Allah Akbar, Allah Akrab. Maumere, Ledalero.

Varshney, Ashutosh, Rizal Panggabean dan Mohammad Zulfan. 2004. Patterns of Collective Violence in Indonesia (1990-2003). Jakarta: UNSFIR.

Wacquant, L.J.D. 1993. 'Thereturnof therepressed: urbanviolence, "race", anddualization in three advanced societies'. Plenary address presented at the XVII Encontro Anual da ANPOCS, October 1993, at Caxambu, Brazil.

Young, Kimball dan Mack W. Raymond. 1959. Sociology and Social Life. New York: American Book Company. 